\title{
Impact of Dupoto-e-Maa education project on dropout rate and academic performance
}

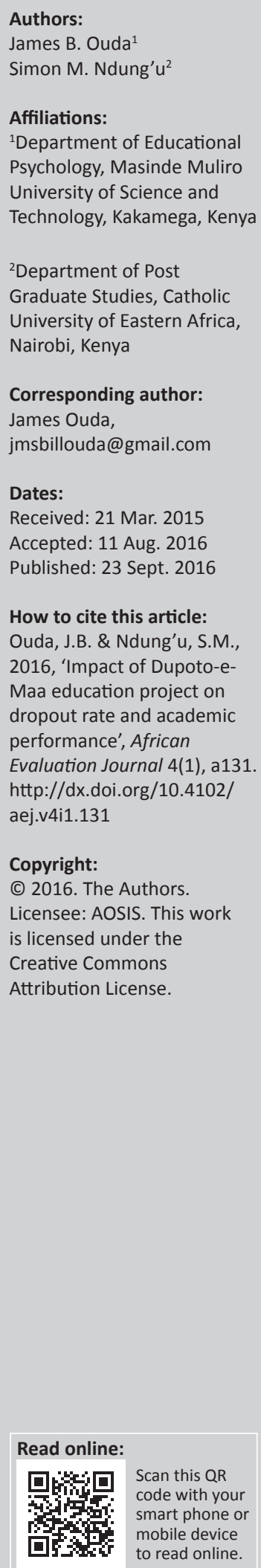

Background: A study conducted in the Kajiado Central District of Kenya in 2006 showed that there was a high dropout rate among primary schoolgoing children and that their academic performance was poor. The Dupoto-e-Maa education project was implemented in 2007 to address issues related to drop out rate and academic performance.

Objectives: The evaluation therefore investigated the extent to which the project had influenced dropout rate and academic performance in the public primary schools in Kajiado Central District.

Method: The evaluation adopted a mixed methods approach: cross-sectional survey and case study designs. The benefit of the approach is the richness of information obtained through triangulation. The respondents included head teachers, school management committees, teachers, pupils, quality assurance and standards officer and project staff. A sample size of 183 respondents was selected using purposive sampling and stratified random sampling procedures. Head teachers of the sampled schools participated as key informants. The instruments of data collection included questionnaires, an interview guide, a document analysis guide, a focus group discussion guide and an observation guide.

Results: The findings indicate that the Dupoto-e-Maa education project had influenced dropout rates. The direction of the findings seems to suggest that academic performance trends are unpredictable since fluctuations are evident, though the programme could have encountered some challenges that may have limited its achievement on this variable.

Conclusion: The study recommended that there is need to increase the number of nongovernmental organisations modelled around the Dupoto-e-Maa education project so as to reduce dropout rate and improve pupil academic performance. The findings could also inform government policy in terms of recruitment and placement of teachers in schools in arid and semi-arid lands. Project funding could be increased to improve visibility and sustainability of project activities.

\section{Introduction}

\section{Background of study}

Education plays a critical role in communities' social, economic and political development. The importance of education has been adequately documented since it serves as the springboard for community change. Long before the coming of Arabs and Europeans to Africa, the African people had developed their own systems of education; although the systems varied from one community to the other, their goals were often strikingly similar (Sifuna \& Otiende 1994).

In many parts of Africa, before independence, schools were primarily run by missionaries, taught basic skills and were often oriented toward producing religious leaders, such as catechists, to assist missionaries in their work (Hodgson 2008). In some of the arid and semi-arid lands (ASALs), the British interest revolved primarily around securing the borders and exerting control over the pastoralist groups of the region. Social services such as education were little developed during the colonial period (Krätli \& Dyer 2009).

Formal, Western-style education was introduced in Kenya in the early 20th century during the colonial conquest of the territory. Most accounts indicate that in the beginning, pastoralists were not enthusiastic about education. As livestock herders dependent on children for herding labour and seasonal mobility for their survival, there was a poor fit between their production system and the design of formal education (Lanyasunya 2012). According to the Bill of Rights, basic education is a fundamental human right (Republic of Kenya 2012). Overall responsibility of guaranteeing 
this right is shared between different persons and institutions. The state and other stakeholders in education like the NonGovernmental Organisations (NGOs), for example Dupotoe-Maa, provide the facilities, parents send their children to school and teachers impart learning (Dadacha 2009).

Lesorogol (2008) suggests that in pastoralist communities, education is often seen as a privilege. It is not. It is one of the fundamental human rights that poor people are denied. Until very recently in the post independence era, the government of Kenya (GoK) was not committed to providing and improving the standard and quality of education in pastoralist communities (Sifuna 2005). Indeed, many Kenyans from pastoralist communities have acquired education due to the benevolence of Catholic missionaries. The number of high school students from the ASALs making it to national secondary schools and public universities remains dismally low (Lanyasunya 2012).

While ASALs cover about $80 \%$ of Kenya's land mass and support about a third of the country's human population and $70 \%$ of the national livestock herd (KNBS 2010), educational disparities between pastoralist districts such as Kajiado Central and the rest of the country remain up to the present. This is consistent with United Nations Education Scientific and Cultural Organization (UNESCO 2005) findings that pastoralist communities around the world have some of the highest dropout rates and lowest academic performance. The figures from the Ministry of Education in Kajiado (MoEST 2005a) put enrolments of girls at $40 \%$ (11 688) compared to $60 \%$ (17 572) for boys with primary school dropout rates of about $50 \%$.

The GoK is cognisant of the education situation in pastoralist communities and is moving towards a positive view of pastoralists' place in a modern, dry land economy (Krätli \& Dyer 2009). This quest is the basis of transformation of our society in key social sectors. The education sector is seen as crucial to the long-term economic blueprint, vision 2030, which plans to make Kenya a middle-income economy in two decades. One of the flagship projects in vision 2030 is to build at least one boarding primary school in each constituency in the pastoral districts. This is to ensure that learning is not disrupted as people move from one place to the other in search of pasture for their livestock (GoK 2007).

In pursuant of the Sustainable Development Goals (SDGs) and Education for All (EFA) goals, coupled with the task of delivering the policies as set in the Sessional Paper No. 1 of 2005 on Policy Framework for Education, Training and Research (MoEST 2005b) and more recently the Sessional Paper No. 14 of 2012 on Policy Framework for Reforming Education and Training Sectors in Kenya, the Republic of Kenya (2012) has been working with stakeholders in education to develop and secure funding for education programmes. This is the basis upon which the government, Ministry of Education Science and Technology (MoEST), individuals, communities, the private sector, NGOs and other development partners jointly support the education sector. The Sessional Paper No.1 of 2005 was developed to help the government achieve the following targets: enhance access, retention, equity and quality in primary education through capacity building for education managers and eliminate gender and regional disparities in basic education, particularly in the ASALs, with the aim of improving pupil academic performance (MoEST 2005b).

The Basic Education Act of 2013 recognises that every child has a right to free and compulsory basic education (Republic of Kenya 2013). The government is committed to ensuring that quality basic education conforms to the set standards and compulsory admission, attendance, retention and completion of basic education by all pupils (MoEST 2005a). In the Act, the government also encourages collaboration and cooperation among education stakeholders involved in governance and management of basic education (Republic of Kenya 2013). In this view, various innovative methods of delivering social services by the stakeholders to pastoralists have come to light. One such initiative is the Dupoto-e-Maa project in Kajiado Central District, Kenya.

The Dupoto-e-Maa (2010) education project for pastoralists, implemented in 2007, covers the remote parts occupied by pastoralists in Kajiado Central District. The project, which is part of an ongoing programme, focuses on the improvement of access and quality of basic education in public primary schools in the remote areas of Kajiado Central District which have no additional interventions to promote basic education besides government efforts through public funding. The purpose of the project, which was implemented for six years, was to enable all eligible pastoralists' children who were out of school in selected areas access to school, and to ensure that those in school remained in school, thus reducing the dropout rate, improving academic performance and attaining gender responsiveness as well as quality basic education. The areas are occupied by pastoralists among whom the majority of the adults are illiterate and high numbers of school age children do not attend school (Timoi 2008).

Timoi (2010) acknowledges that through the project, education stakeholders hoped to increase education opportunities for pastoralist children through policy dialogue and advocacy, sharing of experiences and best practices as well as improved planning. Dupoto-e-Maa is a project through which donors (Edukans Foundation), the community and Dupoto staff members support the GoK to the tune of about US $\$ 11$ million per annum to expand education opportunities as well as improve quality of education for children living in Kajiado Central District (Dupoto-e-Maa 2008b). Marginalised by chronic impoverishment, water scarcity and recurrent famine endemic in the area, children have had among the highest dropout rate and lowest academic performance in Kenya (Timoi 2008). The figures from the MoEST (2005a) put primary school dropout rates at about $50 \%$.

Since it was implemented in 2007, Timoi (2008) informs that the project aimed to improve educational standards among the Kajiado Central District pastoralists. The project aimed to raise the level of participation in education among pastoralists in terms of community participation, access, enrolment, completion, academic performance and both gender and 
geographical equity. The Dupoto-e-Maa (2008a) education project intended to achieve the targets through community awareness creation, provision of facilities, service delivery through workshop training and lobbying and advocacy to raise support by the government. Table 1 shows the Dupotoe-Maa education project logical framework matrix on which the Dupoto-e-Maa education project is anchored.

The intervention or project logical framework shows how the project intended to achieve defined outputs which would in the long run achieve desired outcomes and contribute to the broader project impact. The Objectively Verifiable Indicators (OVIs) and the Means of Verification (MOV) allowed the project to be objectively monitored throughout implementation and evaluated. The logic of the matrix shows what the Dupotoe-Maa education project intended to do and clarifies the causal relationships between the activities and the different level objectives. It also specifies assumptions that must hold true for the project to achieve the intended objective.

\section{Quality basic education}

The Republic of Kenya and UNICEF (2008) appreciate that parents place a high premium on quality education as it is seen as an opportunity to get out of poverty. Provision of quality basic education for all children is an obligation in the convention of the Rights of the Child, but parents in the pastoralist community seem oblivious to this fact (Republic of Kenya 2010). The United Nations International Children Emergency Fund (UNICEF 2008) recognised that quality education includes learners who are healthy, wellnourished and ready to participate and learn and supported in the learning process by their families and community. The education should be offered in environments that are healthy, safe, gender sensitive and protective and provide adequate resources and facilities. According to UNESCO (2005), the teachers should be trained and skillful in pupil assessment to facilitate learning and reduce disparities. Quality basic education includes outcomes that encompass knowledge, skills, attitudes and values and linked to national goals of education and positive participation in society.

\section{Purpose of the evaluation}

The purpose of the study was to conduct a formative evaluation to assess the extent to which the project had influenced dropout rate and academic performance in the project supported public primary schools. Section 43(1) of the Constitution of Kenya provides the right for every Kenyan to education (Republic of Kenya 2010). In pursuance of the two education Millennium Development Goals, to ensure universal primary education and to eliminate gender inequalities, the GoK is conscious of the fact that the same will remain a mirage unless the nomadic pastoralist communities, who have been marginalised, are specifically targeted. Article 3 of the World Declaration on EFA in 1990 identified nomadic pastoralists as one of several groups who are discriminated against in access to education services (WDEFA 1990).

The Ministry of Education (MoE) has developed a Policy Framework for Nomadic Education in Kenya (Republic of Kenya \& UNICEF 2008). Some of the objectives of the policy include reducing dropout rate and improving academic performance in primary education in the pastoralist community. Notwithstanding interventions like the Free Primary Education (FPE) programme, the boarding school initiative and the School Feeding Programme (SFP), children from nomadic pastoralist communities continue to face many barriers including travelling long distances to school to access and complete basic education (Sifuna 2005). In Kajiado Central District, provision of education opportunities faces several challenges. Low population densities and relatively harsh and isolated environments means that there are few and distant schools and qualified teachers are difficult to source (Timoi 2008).

Juma (2010) also recognises that as a result of FPE, there have been reports of lack of an adequate teaching force in pastoralist communities, which does not augur well for basic education being delivered in the public primary school level in Kajiado Central District. As an intervention by education stakeholders the Dupoto-e-Maa education project was implemented to address the challenges faced by pastoralists in terms of dropout rate and academic performance in public primary schools. Since its implementation in 2007, the project has not been evaluated by an external evaluator. Based on this realisation, the purpose of the study was to conduct a formative evaluation by an external evaluator to assess the extent to which the Dupoto-e-Maa project had influenced dropout rate and academic performance for pastoralist children in the project supported public primary schools in Kajiado Central District.

TABLE 1: Dupoto-e-Maa education project logical framework matrix.

\begin{tabular}{llll}
\hline Expected results/outcomes & Intervention logic & Objectively Verifiable Indicators (OVIs) & Means of Verification (MOV) \\
\hline $\begin{array}{l}\text { Enhance academic } \\
\text { performance in the project } \\
\text { schools }\end{array}$ & $\begin{array}{l}\text { Teacher trainees are awarded } \\
\text { bursaries to enrol in TTCs } \\
\text { Teachers employed in schools } \\
\text { are trained }\end{array}$ & $\begin{array}{l}\text { Evidence of mastery of basic concepts by } \\
\text { pupils of numeracy and literacy } \\
\text { Increase of supplementary readers, basic } \\
\text { textbooks, maps and atlas, teachers guide } \\
\text { and syllabuses provided to the project } \\
\text { schools } \\
\text { Improved academic performance } \\
\text { Conduct a three-day training for core } \\
\text { subject teachers on teaching skills }\end{array}$ & $\begin{array}{l}\text { Project school records } \\
\text { Results in district and national }\end{array}$ \\
& & $\begin{array}{l}\text { Teacher trainees will be } \\
\text { willing to attend the } \\
\text { training from beginning to } \\
\text { end and apply the skills } \\
\text { acquired }\end{array}$ \\
$\begin{array}{l}\text { Reduced dropout rates in } \\
\text { basic education for enrolled } \\
\text { pupils }\end{array}$ & $\begin{array}{l}\text { Pupils in the schools have role } \\
\text { models } \\
\text { Adequate education facilities } \\
\text { like classrooms, desks and chairs }\end{array}$ & $\begin{array}{l}\text { Decrease in repetition rates by 40\% } \\
\text { Decrease in dropout rates by 20\% } \\
\text { Improvement in the completion levels for } \\
\text { those already enrolled by 15\% } \\
\text { Improved transition rates }\end{array}$ & $\begin{array}{l}\text { Project schools records and area } \\
\text { education office records }\end{array}$ \\
\hline
\end{tabular}




\section{Evaluation question}

To what extent has the Dupoto-e-Maa education project influenced dropout rate and academic performance in project supported schools in Kajiado Central District?

\section{Literature review on baseline survey}

The Dupoto-e-Maa education project conducted a baseline survey in 2006 before the implementation of the project in 2007 to assess the school dropout rate and academic performance (Timoi 2010).

\section{School dropout}

During the baseline survey, there were three public primary schools in Kajiado Central District with boarding facilities. The primary schools mapped out for the project were predominantly rural with no additional intervention besides public funding (Dupoto-e-Maa 2010). In the 18 project schools, 35\% of the girl population and $28 \%$ of the boy population from pastoralist households had dropped out of school during 2006 (Timoi 2008). If the staffing policy were taken into account, a school with Standard 1-8 will require a minimum of 360 children and 8 teachers. The total number of dropouts in 2006 from the project schools stood at 421 pupils, representing $32 \%$ of the pupil population, and constitutes more than a full school in an area where access and participation are still very low.

In the survey, reasons given for children dropping out of school ranged from religious and cultural beliefs to relocation and transfers. Other reasons for dropping out of school include desertion, death as well as financial reasons and poverty, relocation and transfer, drug and substance abuse, child labour as well as pregnancy. Level of absenteeism was also measured. On average, girls missed school up to three months in a year (Dupoto-e-Maa 2008b).

\section{Academic performance}

Data from the baseline study indicate that between 2005 and 2007, no pupil from the project schools had been admitted to national secondary schools, as most ended up in district schools with a few going to provincial schools (Dupoto-eMaa 2008a). This could be explained as a consequence of poor academic performance in the national examination, Kenya Certificate of Primary Education (KCPE). In 2006, there were only three schools with boarding facilities in Kajiado Central District. Pastoralist children therefore had limited access to boarding schools and had to cope with the sociocultural lifestyle of the community, which led to some of them dropping out of school (Timoi 2008).

The baseline study conducted also established that some schools were not able to complete syllabus coverage within the required time. This occurrence could hinder the intended learning outcomes of the schools (Dupoto-e-Maa 2008b). Though the schools were visited by education officers to assess their service delivery, they did not have adequate physical facilities such as classrooms and sanitation facilities (Dupoto-e-Maa 2008a).

\section{Evaluation design and methodology Evaluation design}

The study adopted a mixed design: a cross-sectional survey and case study research. The mixed design allowed the researcher to collect both qualitative and quantitative data from stakeholders in the Dupoto-e-Maa education project. Quantitative and qualitative designs, as Kerlinger and Howard (1999) note, are more than simply differences between research strategies and data collection procedures. Rather they represent different epistemological frameworks for analysing the nature of knowing, the social reality and the procedures for grasping a phenomenon under investigation. Using both quantitative and qualitative designs can produce a research synergy in which the whole collective benefits are greater than what is obtained from either design alone. Cross-sectional survey allowed the comparison of different population groups as well as use of a variety of data collection instruments. Use of case study design provided the opportunity to use different sources of data. Validity of data was strengthened by using more than one method to conduct the evaluation, which allowed for triangulation, the main advantage of mixed method research design.

\section{Location of study}

The study was conducted in Kajiado Central District, Kajiado County in Kenya, which is classified as ASAL with no continually flowing rivers. It is located in the southern part of Rift Valley province and borders the districts of Machakos and Makueni to the east, Kiambu and Nairobi to the north, Narok and Naivasha to the west and Loitokitok and Republic of Tanzania to the south (Gachimbi 2002).

\section{Target population}

The research population was drawn from 18 public primary schools in Kajiado Central District implementing the Dupoto-e-Maa education project. The population of interest for this study comprised parents in School Management Committees (SMCs), teachers, a Quality Assurance and Standards Officer (QASO) and the administrators of the primary schools implementing the Dupoto-e-Maa education project. SMCs, pupils and project staff were also targeted.

\section{Sample and sampling procedures}

Table 2 shows the population profile and the sample distribution of the study.

Table 2 shows that the study used both probability and nonprobability sampling procedures to select the desired sample for the study. Nine schools were sampled using stratified random sampling. Stratified random sampling was also used to select 12 Class 7 pupils from each school for the focus group discussion (FGD). Four teachers were also selected from each of the sampled schools using stratified random sampling, making a total of 36 teachers. Purposive sampling was used to select three 
TABLE 2: Population profile and sample distribution.

\begin{tabular}{|c|c|c|c|c|}
\hline \multirow[t]{2}{*}{ Categories of population } & \multirow[t]{2}{*}{ Parent population } & \multicolumn{2}{|c|}{ Number of respondents } & \multirow[t]{2}{*}{ Sampling design } \\
\hline & & Sample size & $\%$ & \\
\hline Pupils & 4838 & 108 & 58 & Stratified random sampling \\
\hline Teachers & 183 & 36 & 20 & Stratified random sampling \\
\hline SMC members & 108 & 27 & 15 & Purposive sampling \\
\hline Head teachers & 18 & 9 & 5 & Key informants \\
\hline Project staff & 6 & 2 & 1 & Purposive sampling \\
\hline Total & - & 183 & 100 & - \\
\hline
\end{tabular}

Source: Authors' own work

SMC, School Management Committees; QASO, Quality Assurance and Standards Officer.

TABLE 3: Distribution of the respondents on the influence of Dupoto-e-Maa Project in the retention of schoolgoing children in schools

\begin{tabular}{|c|c|c|c|c|c|c|c|c|c|c|c|c|c|c|}
\hline \multirow[t]{3}{*}{ Statement } & \multicolumn{10}{|c|}{ Teachers } & \multicolumn{2}{|c|}{ Head teachers } & \multirow{3}{*}{$\begin{array}{l}\text { Project } \\
\text { staff (A) }\end{array}$} & \multirow{3}{*}{$\begin{array}{l}\text { QASO } \\
\text { (A) }\end{array}$} \\
\hline & \multicolumn{2}{|c|}{ SA } & \multicolumn{2}{|c|}{ A } & \multicolumn{2}{|c|}{ u } & \multicolumn{2}{|c|}{ D } & \multicolumn{2}{|c|}{ SD } & \multirow{2}{*}{$\begin{array}{c}\mathrm{A} \\
\mathrm{F}\end{array}$} & \multirow{2}{*}{$\frac{D}{F}$} & & \\
\hline & $F$ & $\%$ & $\mathbf{F}$ & $\%$ & $\mathbf{F}$ & $\%$ & $F$ & $\%$ & $F$ & $\%$ & & & & \\
\hline $\begin{array}{l}\text { Dropout rate among pupils in my } \\
\text { school has reduced since the } \\
\text { introduction of Dupoto-e-Maa } \\
\text { education project. }\end{array}$ & 10 & 30.3 & 10 & 30.3 & 13 & 39.4 & - & - & - & - & 6 & 2 & 2 & 1 \\
\hline $\begin{array}{l}\text { Class attendance of school age } \\
\text { children have increased over the } \\
\text { last two years in my school. }\end{array}$ & 10 & 30.3 & 15 & 45.5 & 8 & 24.2 & - & - & - & - & 7 & 1 & 2 & 1 \\
\hline $\begin{array}{l}\text { More parents in this region are } \\
\text { willing to ensure that the } \\
\text { education of their children is not } \\
\text { affected by their pastoral life. }\end{array}$ & 15 & 45.5 & 8 & 24.2 & - & - & 5 & 15.6 & 5 & 15.6 & 5 & 3 & 2 & 1 \\
\hline Total & 35 & 106.1 & 33 & 100 & 21 & 63.6 & 5 & 15.2 & 5 & 15.6 & 18 & 6 & 6 & 3 \\
\hline Average mean score & 12 & 35.4 & 11 & 33.3 & 7 & 21.2 & 2 & 5.2 & 2 & 5.2 & 6 & 2 & 2 & 1 \\
\hline
\end{tabular}

Source: Authors' own work

SA, Strongly agree; A, Agree; U, Undecided; D, Disagree; SD, Strongly disagree; F, Frequency

SMC members from each of the sampled schools, giving a total of 27 SMC members. The head teachers of each of the sampled schools were included in the study as key informants. Two project staff and a QASO were also purposively sampled. In total, 183 respondents were sampled for the study.

\section{Data collection instruments}

The evaluator used a questionnaire for teachers and project staff. Questionnaires are useful in describing the characteristics of a large population. Surveys are flexible, making it possible to ask many questions on a given topic. This also provides flexibility in the analysis of the responses. An interview guide was used for the QASO, head teachers and parents. Interviews enabled the researcher to establish a rapport with respondents and therefore gain their corporation and in the process yield a higher response rate. An FGD guide for pupils was used to collect information from them. The FGD allowed the moderator to probe for more in-depth analysis and ask participants to elaborate on their responses. An observation guide was also used to collect data on school physical facilities and a document analysis schedule was used to collect data.

\section{Presentation of findings, conclusion and recommendations \\ Impact of Dupoto-e-Maa project on dropout rates in project supported schools}

The Dupoto-e-Maa education project post intervention results were obtained in 2014. The project had been involved in activities geared towards reducing pupil dropout rate in project supported primary schools. These include creating awareness among the education stakeholders on the importance of education through training workshops.

\section{Effect of Dupoto-e-Maa project on retention rate of pupils}

An overwhelming majority of the sampled teachers (82\%) felt that since the introduction of the Dupoto-e-Maa education project, the retention rate of children in schools had increased. However, a few of them (18\%) said that the retention rate had not increased. The majority of the respondents (67\%) opined that the dropout rate of the pupils was not as high since the implementation of the Dupoto-e-Maa project.

The respondents were further asked to indicate their extent of agreement to various statements regarding the influence of the Dupoto-e-Maa project on the retention of pupils in schools.

As depicted in Table 3, about a third of the sampled teachers $(30.3 \%)$ strongly agreed that the rate of dropout among school age children in their respective schools had reduced since the introduction of Dupoto-e-Maa education project. This was further supported by another $30.3 \%$ who agreed with the statement. The reduced dropout rates could be attributed to the increased number of schools with boarding facilities. The statistic for the category of schools supported by the Dupoto-e-Maa education project show that the number of project schools with boarding facilities in the district had increased from the initial number of three in 2007 during the initial period of the implementation of the project. Six schools out of the sampled schools had boarding facilities. 
The majority of the sampled teachers (75.8\%) either strongly agreed or agreed with the statement that class attendance of school age children had increased over the last two years in their school. About half of the teachers (45.5\%) strongly agreed with the statement that more parents in their region were willing to ensure that the education of their children is not affected by their pastoral life. However, about a third of them (31.2\%) either disagreed or strongly disagreed with the statement that parents were more willing to ensure that education of their children was not affected by the pastoral life.

Regarding whether the Dupoto-e-Maa education project influenced retention of pupils in the project supported schools, the majority of the teachers $(68.7 \%)$ confirmed that the project influenced retention rates of schoolgoing children. Further, most of the head teachers (6) from the sampled schools agreed that the project had indeed influenced retention rates in schools. The same response was obtained from the two project staff and one QASO.

The majority of the responding head teachers and parents were in agreement that the activities of the Dupoto-e-Maa project had contributed to the reduction of dropout rates among children and improved class attendance. (On the same subject, one of the head teachers said this):

'The Dupoto-e-Maa education project had created [a] conducive environment within the school compound. This had led many parents to trust the schools and especially regarding the safety of their children. As such, during the dry seasons while moving with their livestock in search of pasture, parents opt to admit their children to boarding schools so that their education is not interrupted.' (Head Teacher V, 2013)

On probing as to what he meant by conducive environment, the head teacher elaborated by saying:

'The project had addressed the issue of school infrastructure. It was involved in the construction, refurbishment and renovation of the school infrastructure including classrooms, dormitories, desks and school kitchen have been built by the project.' (Head Teacher V, 2013)

Another head teacher gave her view:

'There was increased number of men and women from the local community, who have joined the schools as teachers, hence act as role models to the boys and girls in school. This makes both the parents and pupils appreciate the importance of education.' (Head Teacher VII, 2013)

Most of the parents (78\%) were optimistic regarding the effects of the Dupoto-e-Maa education project on the retention rate of the pupils in school.

In fact, one of the parents who participated in the study reported:

'The project had influenced the retention rate of the pupils in schools to a greater extent. This improvement had been realized because the project had supported schools with boarding facilities like dormitories and beddings. As a result, we parents opt to send our children to boarding school. This helps to avoid interruptions of their studies by our movements during the dry seasons in search of pastures for our animals.' (Parent XIV, 2013)

Another parent, contributing to the theme of dropout rate, commented:

'We are now aware that basic education for our children is a human right. Most of the parents were not aware of this fact before the project.' (Parent XX, 2013).

The pupils were also positive that the project had contributed in improving their retention rates in school. Most of them indicated that the continued motivational talks encouraged by the project for schools were very important because they have helped to create a positive outlook on education and it benefits.

\section{Dropout rate}

The dropout rate was assessed in terms of number of pupils dropping out of school annually. Document analysis was carried out to gain insight into the exact picture of the dropout rates of pupils in project schools in the Kajiado Central District for the period 2008-2013. The analysis from school records are summarised in Table 4.

It is critical to note that the annual dropout rate reduced from $32 \%$ in 2006 during the baseline survey. Looking at the rates $(2.2 \%, 3.1 \%, 4.2 \%, 2.2 \%$ and $2.1 \%)$ in Table 4 , we can say that the curve on dropout rate is not regular; the rates are in line with the OVIs in Table 1, to reduce the dropout

TABLE 4: Summary of the dropout rate per year for the period of 2008-2013.

\begin{tabular}{|c|c|c|c|c|c|c|c|c|c|c|c|c|}
\hline \multirow[t]{2}{*}{ School } & \multicolumn{2}{|c|}{2008} & \multicolumn{2}{|c|}{2009} & \multicolumn{2}{|c|}{2010} & \multicolumn{2}{|c|}{2011} & \multicolumn{2}{|c|}{2012} & \multicolumn{2}{|c|}{2013} \\
\hline & B & $\mathbf{G}$ & B & G & B & G & B & $\mathbf{G}$ & B & G & B & G \\
\hline 1 & - & - & - & - & 1.8 & 1.8 & 2.0 & 2.7 & 0.8 & 1.8 & 1.0 & 1.3 \\
\hline II & - & - & - & - & - & 1.9 & - & - & - & 1.4 & - & 0.8 \\
\hline III & - & - & 1.6 & 2.7 & 4.6 & 5.4 & 4.0 & 6.2 & 3.3 & 2.0 & - & - \\
\hline IV & - & - & - & - & 6.6 & - & 2.4 & 7.8 & - & 1.9 & - & - \\
\hline V & - & - & - & - & 2.1 & - & 2.4 & 3.2 & 1.4 & 1.0 & 1.7 & 4.1 \\
\hline $\mathrm{VI}$ & - & - & - & - & 2.6 & - & - & 10.1 & 3.6 & 4.9 & - & 4.7 \\
\hline VII & - & - & 1.4 & 3.1 & - & - & 3.0 & 2.9 & - & - & 2.3 & 4.4 \\
\hline VIII & - & - & 1.9 & 2.8 & 0.7 & 3.3 & - & - & - & - & 0.3 & 1.7 \\
\hline \multirow[t]{2}{*}{ Total } & - & - & 1.6 & 1.8 & 3.1 & 3.1 & 2.8 & 5.5 & 2.3 & 2.2 & 1.3 & 2.8 \\
\hline & \multicolumn{2}{|c|}{-} & \multicolumn{2}{|c|}{2.2} & \multicolumn{2}{|c|}{3.1} & & & \multicolumn{2}{|c|}{2.2} & \multicolumn{2}{|c|}{2.1} \\
\hline
\end{tabular}

Source: Authors' own work

$\mathrm{G}$, girls; B, boys. 
rate by $20 \%$. The positive development could be attributed to the Dupoto-e-Maa education project and its efforts in improving the overall retention rates of pupils in schools. However, despite the project activities and efforts made, there were still a number of children who continued dropping out of school, thus affecting their studies. A primary census that was conducted by MoEST (2005b) showed that the commonest reason for dropping out of school was lack of interest on the part of parents owing to their own illiteracy. This is in line with findings of this study where the majority of parents who participated in the study were found to have no education or only completed the primary level of education.

\section{Effect of Dupoto-e-Maa education project on academic performance}

The majority of the teachers $(81.8 \%)$ indicated that the implementation of the Dupoto-e-Maa project had influenced the overall academic performance. However, a few of them (18.2\%) appeared not to agree that the academic performance in their respective school was influenced by the Dupoto-eMaa project. The head teachers and project staff also indicated that the overall academic performance of the school was mainly influenced by the implementation of the Dupoto-e-Maa education project. Further, the respondents were asked to indicate their extent of agreement on the influence of Dupoto-e-Maa Education project in the improved performance in primary schools.

Over half of the teachers (54.5\%) were positive about the statement that implementation of the Dupoto-e-Maa Education project had influenced the overall academic performance of their schools to a greater extent. This was further supported by about a third of them (30.3\%) who agreed that it did influence academic performance to some extent. On the other hand, a good number of head teachers (5) indicated that the project had influenced the performance of pupils in their respective schools to a greater extent. Moreover, the remaining three head teachers indicated that the project had influenced the performance of pupils in their school, but only to some extent.
The respondents were asked to indicate their levels of agreement regarding the effects of Dupoto-e-Maa education project on the academic performance of pupils in the project supported schools.

Table 5 shows that over half of the teachers (51.5\%) strongly agreed that the implementation of the Dupoto-e-Maa education project had not addressed the issue of teacher adequacy and this had affected the overall performance of students. This was further supported by over a third of them $(36.7 \%)$ who agreed that the project had not addressed the issue of teacher adequacy. In contrast, $12.1 \%$ of the teachers who responded were of the opinion that the project had addressed teacher adequacy in schools hence improved academic performance.

As depicted in Table 5, the majority of the teachers (66.7\%) either disagreed or strongly disagreed with the statement that despite the project implementation, the performance of pupils was still poor. Despite the findings it must be appreciated that the performance of children from pastoralist communities in Kenya is perceived to be below the national average (Sifuna, 2005). Many challenges adversely affect pupil enrolment, regular attendance and academic performance in school: lack of schools, the distance they must walk to go to school, a dangerous environment to walk through, school fees, lack of food among others. All these factors are found to greatly affect the academic performance of both boys and girls, but have the greatest impact on girls (Muhammad 2008).

Table 5 shows that almost half of the teachers (48.4\%) either strongly agreed or agreed that the project had not been able to facilitate enrolment of teachers for training in colleges and hence academic performance still remains poor among pupils. However, almost an equal number of them (42.3\%) either disagreed or strongly disagreed with the statement. The findings indicate that though some teachers were trained, the number may not be adequate.

Less than half of the teachers (48.5\%) as depicted in Table 4 strongly agreed that despite the project implementation,

TABLE 5: Distribution of the respondents on the influence of Dupoto-e-Maa project on the academic performance of pupils in the project supported schools.

\begin{tabular}{|c|c|c|c|c|c|c|c|c|c|c|c|c|c|}
\hline \multirow[t]{3}{*}{ Response } & \multicolumn{10}{|c|}{ Teachers } & \multicolumn{2}{|c|}{ Head teachers } & \multirow{3}{*}{$\frac{\frac{\text { Project staff }}{\text { D }}}{\text { F }}$} \\
\hline & \multicolumn{2}{|c|}{ SA } & \multicolumn{2}{|c|}{ A } & \multicolumn{2}{|c|}{ U } & \multicolumn{2}{|c|}{ D } & \multicolumn{2}{|c|}{ SD } & \multirow{2}{*}{$\begin{array}{l}\mathrm{A} \\
\mathrm{F}\end{array}$} & \multirow{2}{*}{$\begin{array}{l}\mathrm{D} \\
\mathrm{F}\end{array}$} & \\
\hline & $F$ & $\%$ & $\mathbf{F}$ & $\%$ & $\mathbf{F}$ & $\%$ & $\mathbf{F}$ & $\%$ & $F$ & $\%$ & & & \\
\hline $\begin{array}{l}\text { The project has not addressed } \\
\text { teacher adequacy hence } \\
\text { affecting performance. }\end{array}$ & 17 & 51.5 & 12 & 36.7 & - & - & 4 & 12.1 & - & - & 5 & 3 & 2 \\
\hline $\begin{array}{l}\text { Despite the project } \\
\text { implementation pupil } \\
\text { performance is still poor. }\end{array}$ & - & - & - & - & 11 & 33.3 & 15 & 45.5 & 7 & 21.2 & - & 8 & 2 \\
\hline $\begin{array}{l}\text { The project has not been able } \\
\text { to facilitate teacher training } \\
\text { enrolment in colleges. }\end{array}$ & 6 & 18.1 & 10 & 30.3 & 3 & 9.1 & 8 & 24.2 & 6 & 18.1 & 5 & 3 & 2 \\
\hline $\begin{array}{l}\text { Despite the project } \\
\text { implementation, education } \\
\text { quality has not been addressed } \\
\text { leading to poor performance. }\end{array}$ & 16 & 48.5 & - & - & 6 & 18.2 & 11 & 33.3 & - & - & 2 & 6 & 2 \\
\hline Total & 39 & 118.1 & 22 & 67 & 20 & 60.6 & 38 & 115.1 & 13 & 39.3 & 12 & 20 & 8 \\
\hline Average mean score & 10 & 29.5 & 6 & 16.8 & 5 & 15.2 & 10 & 28.8 & 3 & 9.8 & 3 & 5 & 2 \\
\hline
\end{tabular}

Source: Authors' own work

SA, Strongly agree; A, Agree; U, Undecided; D, Disagree; SD, Strongly disagree; F, Frequency. 
quality of education has not been addressed and thus pupils still lacked access to quality education. This was however not the case among a third of them $(33.3 \%)$ who disagreed that despite project implementation, quality of education had not been addressed. In line with this finding, an early study conducted by UNESCO (2005) showed that despite the interventions made to increase the enrolment of pupils in schools, the quality of education is compromised in terms of lack of schools, the distance pupils must walk to go to school, the dangerous environments they must walk through, fees, lack of food, poor standards of education in the schools and lack of classrooms, books, desks, teachers and learning supplies.

Regarding whether the Dupoto-e-Maa project influenced the academic performance of pupils in the project supported schools, the responses from the teachers presented mixed results. Slightly less than half $(46.3 \%)$ of teachers confirmed that the pupils' performance was influenced by the project's interventions. However, another $38.6 \%$ of them were negative about whether the project influenced their performance. Further, most of the head teachers (5) also disagreed that the project influenced pupils' performance. Three of them however agreed that the project had some influence on academic performance of pupils.

In response to the effects of the Dupoto-e-Maa education project on the academic performance of pupils in project supported schools in Kajiado Central District one of the head teachers commented:

'The performance of pupils in his school has been steadily improving since the introduction of the Dupoto-e-Maa education project. This is evident with the improved class mean scores of pupils both in the upper and lower classes.' (Head Teacher II, 2013)

To emphasise the point on improved academic performance the teacher continued:

'Before the implementation of the project, none of our pupils used to join national secondary schools after KCPE. Since the project, some of our pupils have been admitted to national secondary schools as well as county secondary school.' (Head Teacher II, 2013)

Commenting on the same issue of academic performance, another head teacher remarked:

'The performance of pupils in the primary schools which are supported by the Dupoto-e-Maa education project continues to get better each day. Moreover, the project has facilitated the enrolment of untrained teachers in the Teacher Training Colleges [TTCs].' (Head Teacher VI, 2013)

Asked whether academic performance had improved since the implementation of the project, another head teacher remarked that the performance was mixed. When probed to elaborate on her response, she said:

'Some of the pupils have to walk long distances to school and therefore always arrive late for lessons. These same pupils are unable to go home for lunch due to the distance. At the same time, schools are unable to provide lunch because of limited resources. Therefore they have to attend the afternoon lessons on an empty stomach.' (Head Teacher VII, 2013)

As she adjusted her sitting position and continued, the researcher enquired on what can be done to address the concerns she had raised. She replied with this statement:

'Introduction of boarding facilities for all pupils in the school will go a long way in solving these challenges. Currently in most of the schools, including mine, the boarding facilities, though available, are inadequate and therefore used by Class 7 and Class 8 only and more so when the exams are approaching. In the rest of the year the Class 7 and Class 8 are day scholars.' (Head Teacher VII, 2013)

The parents interviewed also gave various responses regarding the effect that the Dupoto-e-Maa education project had on academic performance. One of them reported:

'The Dupoto-e-Maa education project contributed to improved academic performance of pupils in the schools through various ways, including the introduction of monitoring and evaluation practices. We are encouraged to visit the class teacher at least twice a term to monitor the child's academic progress.' (Parent XX, 2013)

\section{Overall Kenya Certificate of Primary Education performance for the period 2007-2012}

Further, document analysis was carried out to review the overall KCPE performance of the pupils in the project supported schools for the period 2007-2012. KCPE is an annual examination that is done after eight years of the primary education programme.

As shown in Table 6, the overall performance of pupils has not been consistent. Over the years, the schools have been posting mixed results in KCPE. For instance, in the year 2007 the average performance of the schools was $48.97 \%$. In 2008, the performance improved to $49.70 \%$ but then dropped in 2009 to $45.38 \%$. As such, there is more that needs to be done to ensure that the average performance of schools in the final examinations not only improves but also shows consistency. UNESCO (2005) opines that despite interventions made in pastoralist communities to increase enrolment and improve academic performance of pupils in schools, the quality of education is compromised by lack of adequate number of schools, the distance pupils must walk to go to school, poor standards of education in the schools and lack of classrooms, books, desks, teachers and learning supplies and this affects

TABLE 6: Overall performance of Kenya Certificate of Primary Education (KCPE) for the period of 2007-2012.

\begin{tabular}{lllllll}
\hline School & $\mathbf{2 0 0 7}$ & $\mathbf{2 0 0 8}$ & $\mathbf{2 0 0 9}$ & $\mathbf{2 0 1 0}$ & $\mathbf{2 0 1 1}$ & $\mathbf{2 0 1 2}$ \\
\hline I & 50.41 & 53.14 & 50.87 & 52.66 & 48.33 & 50.75 \\
II & 56.58 & 60.12 & 56.57 & 57.83 & 55.49 & 54.02 \\
III & 45.27 & 41.94 & 37.18 & 49.80 & 41.31 & 35.91 \\
IV & 52.55 & 51.58 & 39.68 & 41.00 & 47.44 & 49.47 \\
V & 46.80 & 45.80 & 48.60 & 38.80 & 48.60 & 53.80 \\
VI & 49.16 & 49.83 & 46.32 & 46.76 & 44.20 & 38.12 \\
VII & 47.28 & 49.75 & 45.89 & 46.00 & 44.04 & 44.95 \\
VIII & 43.74 & 45.46 & 37.89 & 39.93 & 46.17 & 46.49 \\
\hline Average & $\mathbf{4 8 . 9 7}$ & $\mathbf{4 9 . 7 0}$ & $\mathbf{4 5 . 3 8}$ & $\mathbf{4 6 . 6 0}$ & $\mathbf{4 6 . 9 5}$ & $\mathbf{4 6 . 6 9}$ \\
\hline
\end{tabular}

Source: Authors' own work 
the performance of pupils in schools. This finding is consistent with the results of School II. The school is a girls' only boarding school. Pupils do not have to walk long distances to school and food is also available. Its general performance is better than the other schools. Perhaps the boarding facility plays a significant role in improved academic performance.

\section{Conclusion}

The Dupoto-e-Maa education project had influenced the dropout rates of pupils enrolled in the project supported schools in Kajiado Central District to a greater extent. The dropout rate reduced from $32 \%$ in 2006 to less than $20 \%$ during project implementation, thus achieving the project's objective on the theme of reduced dropout rates. Results obtained from the study indicate that the number of project schools with boarding facilities had increased since the project was implemented. This had contributed to the increased attendance of school age children in schools and it had also influenced more parents to willingly ensure that the education of their children is not affected by their pastoralistic life. This had contributed to reducing the dropout rates in schools. The findings on dropout rates therefore suggest that the project has significantly contributed to reduced dropout rates, although a deliberate sustained effort is still required to reduce the figures even further.

The project has shown mixed results on its effect on the academic performance of pupils in the project supported schools. This was contrary to expectations. The data analysed indicate fluctuation in academic performance during the project implementation period. Evidence shows that academic performance is unpredictable since said fluctuations are evident. Academic results notwithstanding, it must be recognised that the project was engaged in activities geared towards improving pupil academic performance. The project made deliberate effort to address the adequacy as well as capacity of teachers. The project also facilitated the enrolment of teachers in TTCs as one of the interventions of improving performance. While it may not be conclusive, the direction of the findings seems to suggest that academic performance is on an upward trajectory, although the programme may have encountered some challenges that could have limited its achievement on this variable.

\section{Recommendations}

Based on the findings, the study recommends the following measures:

There is a need for increased financial resources for the project through links with national programmes like the Constituency Development Fund and the local county government of Kajiado so as to facilitate project activities. This would also increase the visibility of the project activities on reducing dropout rate and improving academic performance and hence improve the project sustainability.

Address the issues of policy dialogue at national level with regard to teacher recruitment and deployment to ASALs. The
GoK, through the MoE needs to review some of its policies, especially on teacher appointment and placement.

There is a need to explore the use of multi-pronged approaches to provision of education, including boarding facilities, financed by both central and local government and not left entirely to the communities. It must be noted, however, that local support and participation increases the chances of sustainability.

Upscale complementary initiatives by NGOs should be implemented in a deliberate and planned fashion for wider coverage.

\section{Acknowledgements}

This research was made possible with the hard work and contributions of all participants and the participating organisation, the Dupoto-e-Maa education project. We also wish to recognise the contributions of Dr Pascal Wambiya of Catholic University of Eastern Africa, Nairobi, Kenya, and Dr Robert Kamau of Mount Kenya University, Thika, Kenya, for reviewing our work and giving constructive comments that helped improve it.

\section{Competing interests}

The authors declare that they have no financial or personal relationships that may have inappropriately influenced them in writing this article.

\section{Authors' contributions}

J.B.O. was responsible for the research design, writing case studies and conducting questionnaires and the majority of interviews as well as FGDs. S.M.N., co-designer of the research, conducted some of the focus groups and interviews. All authors were involved in the analysis of data and report writing.

\section{References}

Dadacha, G.L., 2009, Kenya: The politics of deprivation and separation - The case of Northern Kenya. Paper presented at the fourth session of the National Youth Convention, Nairobi, Kenya.

Dupoto-e-Maa, 2008a, A project to improve participation of pastoralists in gender sensitive quality basic education, Olkejuado Pastoralists Development Organization., Kajiado, Kenya.

Dupoto-e-Maa, 2008b, Promoting pastoralists basic education program. Olkejuado Pastoralists Development, Kajiado, Kenya

Dupoto-e-Maa, 2010, Promoting pastoralists basic education II. Olkejuado Pastoralists Development Organization., Kajiado, Kenya

Gachimbi, L.N., 2002, Technical report of soil survey and sampling results: Embu Mbeere Districts, Kenya, Land Use Change Impacts \& Dynamics (LUCID), Project Working Paper, International Livestock Research Institute, Nairobi, Kenya.

Hodgson, D.L., 2008, The Church of women: Gendered encounters between Maasai and missionaries, Indiana University Press, Bloomington, IN

Juma, M., 2010, 'Security and regional cooperation in Africa: How can we make Africa's security architecture fit for the new challenges?' in Heinrich Böll Foundation, Climate change, resources, migration: Securing Africa in an uncertain climate, Heinrich Böll Foundation Southern Africa, Cape Town, pp. 16-25,

Kenya National Bureau of Statistics (KNBS), 2010, 2009 Kenya population and housing census, KNBS, Nairobi.

Kerlinger, F.N. \& Howard, B.L., 1999, Foundation of behavioral research, 4th edn., HBJ College and School Division, New York, NY. 
Krätli, S. \& Dyer, C., 2009, Educating mobile pastoralists: A strategic review of literature, Education for Nomads Issues Paper \#1, IIED, London.

Lanyasunya, A.R., 2012, 'Factors affecting access to basic formal education among nomadic pastoralists of Northern Kenya: A case of Samburu', Research on Humanities and Social Sciences 2(10), 124-131.

Lesorogol, C.K., 2008, 'Setting themselves apart: Education, capabilities and sexuality among Samburu women in Kenya', Anthropological Quarterly 81(2), 551-577. http://dx.doi.org/10.1353/anq.0.0020

Ministry of Education Science and Technology, 2005a, Sessional paper 1 of 2005 on policy framework for education, training and research, Government Printers, Nairobi.

Ministry of Education Science and Technology, 2005b, Kenya Education Sector Support Programme [KESSP] 2005-2010, MOEST, Nairobi.

Muhammad, M.A. (2008). Pastoralists girls' education in Africa: A study of Emusoi Center in northern Tanzania, GRIN Publishing, Munich. Available from http:// center in northern Tanzania, GRIN Publishing, Munich. Available from http:// of-emusoi-center-in-northern

Republic of Kenya, 1998, Master plan on education and training, 1997-2001, Government Printer, Nairobi.

Republic of Kenya, 2010, The constitution of Kenya, National Council for Law Reporting, Office of Attorney General, Nairobi.

Republic of Kenya, 2012, Sessional Paper No. 14 of 2012 on Reforming Education and Training Sectors in Kenya, Government Printers, Nairobi.
Republic of Kenya, 2013, The Basic Education Act, Government Printers, Nairobi.

Republic of Kenya \& UNICEF, 2008, Policy framework for Nomadic Education in Kenya, Government Printers, Nairobi.

Sifuna, D., 2005, 'Increasing access and participation of pastoralist's communities in primary education in Kenya', International Review of Education 51(56), 499-516. http://dx.doi.org/10.1007/s11159-005-8260-9

Sifuna, D.N. \& Otiende, J.E., 1994, An introductory history of education, Nairobi University Press, Nairobi.

Timoi, S.S., 2008, Pastoralist education annual report, Activity report, Olkejuado Pastoralists Development Organization, Kajiado District, Kenya.

Timoi, S.S., 2010, Promoting pastoralists basic education program in Kajiado Kenya, Olkejuado Pastoralists Development Organization, Kajiado District, Kenya.

United Nations Education Scientific and Cultural Organization (UNESCO), 2005, Education for all: The leap to equality, EFA Global Monitoring Report 2003-04, viewed 01 May 2007, from portal.unesco.org/education/en/ev.php-url id= 23023\&url do=do_topic\&url section $=201 . \mathrm{html}$

United Nations International Children Emergency Fund (UNICEF), 2008, Curriculum report card, Working Paper Series, Education Section, Programme Division, UNICEF, New York, NY.

World Declaration of Education for All (WDEFA), 1990, World declaration of education for all: Meeting basic learning needs, World Conference on Education for All, Jomtien, Thailand. 